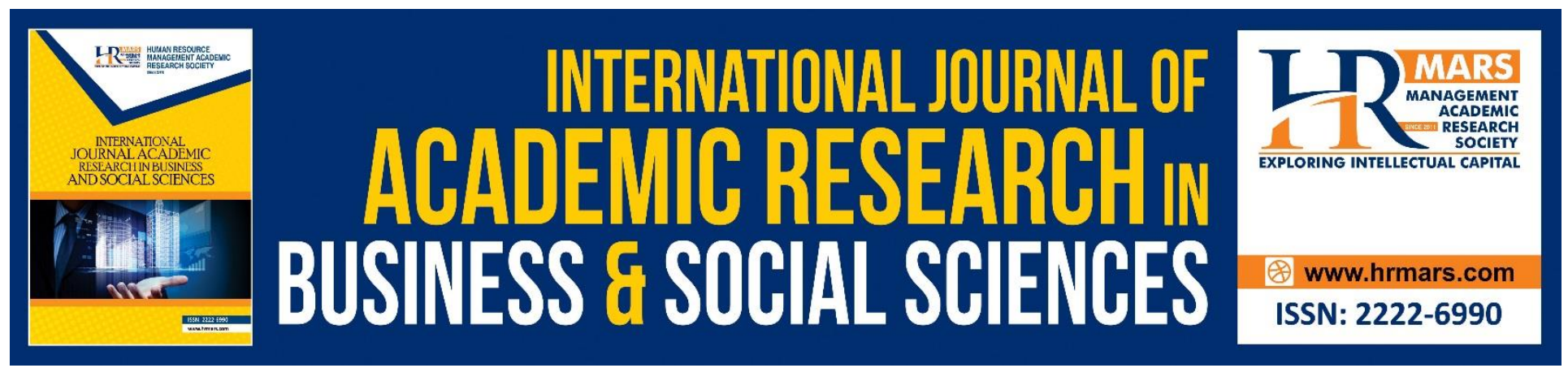

\title{
The Role of Zakat Distribution in Hunger and Poverty Elimination in Kedah
}

\section{Yusuf Haji-Othman, Mohd Sholeh Sheh Yusuff \& Mohammadtahir Cheumar}

To Link this Article: http://dx.doi.org/10.6007/IJARBSS/v10-i10/8277

DOI:10.6007/IJARBSS/v10-i10/8277

Received: 23 August 2020, Revised: 20 September 2020, Accepted: 19 October 2020

Published Online: 30 October 2020

In-Text Citation: (Haji-Othman et al., 2020)

To Cite this Article: Haji-Othman, Y., Yusuff, M. S. S., \& Cheumar, M. (2020). The Role of Zakat Distribution in Hunger and Poverty Elimination in Kedah. International Journal of Academic Research in Business and Social Sciences, 10(10), 1178-1184.

Copyright: (c) 2020 The Author(s)

Published by Human Resource Management Academic Research Society (www.hrmars.com)

This article is published under the Creative Commons Attribution (CC BY 4.0) license. Anyone may reproduce, distribute, translate and create derivative works of this article (for both commercial and non-commercial purposes), subject to full attribution to the original publication and authors. The full terms of this license may be seen

at: http://creativecommons.org/licences/by/4.0/legalcode

Vol. 10, No. 10, 2020, Pg. 1178 - 1184

Full Terms \& Conditions of access and use can be found at http://hrmars.com/index.php/pages/detail/publication-ethics 


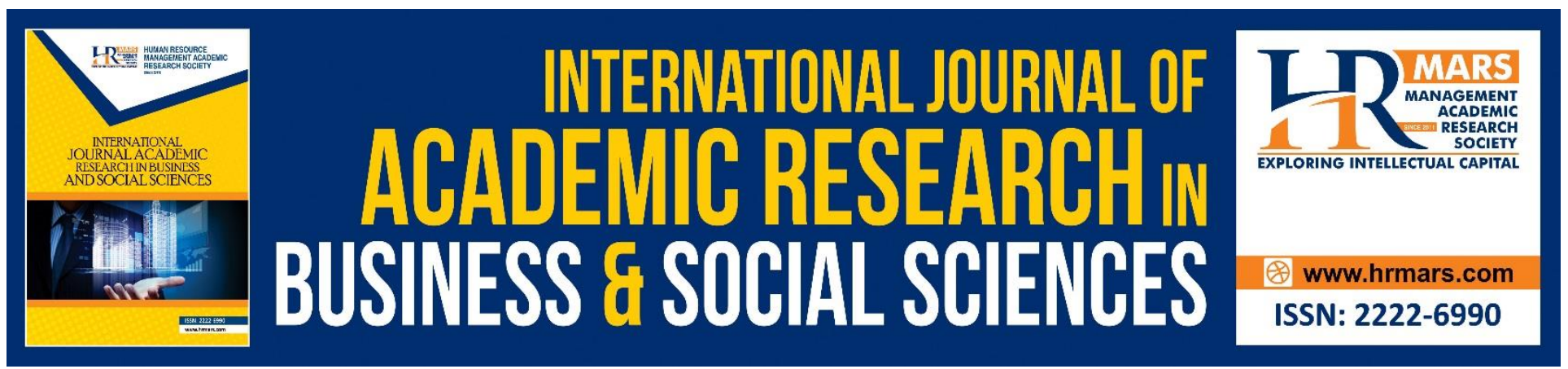

\title{
The Role of Zakat Distribution in Hunger and Poverty Elimination in Kedah
}

\section{Yusuf Haji-Othman, Mohd Sholeh Sheh Yusuff \& Mohammadtahir Cheumar}

Sultan Abdul Halim Mu'adzam Shah International Islamic University Kedah

\begin{abstract}
Zakat is not only a religious obligation which must be complied by all eligible Muslims but also plays a very important role in Islamic fiscal system, specifically as a major source of income and could be used as an instrument to finance certain programs to achieve social, political and economic development among Muslim communities. However, the standard goals to be achieved by zakat distribution across the world are still ambiguous and therefore, need to be examined. The objective of this study is to examine the role of zakat distribution in the state of Kedah, Malaysia in assisting to achieve the goals of hunger and poverty elimination. This study is hoped to shed some light on whether the distribution of zakat in Kedah is in line with the goals, which could expand our understanding of the effectiveness of zakat distribution in achieving the objective of zakat. This study employs a descriptive analysis to answer research objectives to provide empirical evidence and justifications to the analysis. This study employs secondary data on zakat distribution published by KSZB. This study makes a concerted effort to analyze zakat distribution in the state of Kedah, Malaysia, and its role in the elimination of hunger and poverty. This study reveals that KSZB has made important strides towards achieving the goal of eliminating hunger and poverty. Although there is a great potential to achieve the goals through zakat distribution, its success still depends upon the amount of zakat collection. The zakat collection needs to be increased up to the target collection to have enough funds to be distributed to the recipients. KSZB needs to plan, strategize, and implement a suitable and effective zakat distribution policy to speed up the process of achieving the goals of hunger and poverty elimination.
\end{abstract}

Keywords: Zakat Distribution, Hunger, Poverty, Elimination, Sustainable Development Goals.

\section{Introduction}

Zakat means purity, growth, increase, and cleanliness (Abd Halim et al. 2012; Hj Ibrahim, 2008; Ali et al., 2014). Zakat payment is a religious obligation (Saeed Siddiqi, 1984; Triyuwono \& Riduwan, 2012; Norazlina \& Abdul Rahim, 2011). Zakat is the most important fiscal revenue in an Islamic economy. Zakat collection and distribution is the core of the Islamic fiscal policy, and the other core is nonzakat revenues and expenditure. The collection and distribution of zakat are the most important function of the Islamic fiscal policy. Therefore, zakat is the heart of the Islamic fiscal policy. 
Furthermore, zakat is also part of Islamic finance. During the time of the Prophet, there were no financial duties other than zakat which was imposed on the people in the second year after the hijra. There were no taxes levied on the people during that time (Nur Barizah \& Majdi, 2010; Abu Bakar \& Abdul Rahman, 2007).

In short, zakat is not only a tool of Islamic public finance and a tool of redistribution of income but also acts as a mechanism of development and poverty alleviation. Zakat is not only a religious obligation which must be complied by all eligible Muslims but also plays a very important role in Islamic fiscal system, specifically as a major source of income and could be used as an instrument to finance certain programs to achieve social, political and economic development among Muslim communities. However, the standard goals to be achieved by zakat distribution across the world are still ambiguous and therefore, need to be examined.

To further examine the distribution of zakat in Kedah and its relation to elimination of hunger and poverty, we need to understand the Sustainable Development Goals (SDGs) because hunger ang poverty eliminations are among the main goals of SDGs. SDGs and the 2030 agenda is the plan of action which targets to change and improve people's lives and prosperity throughout the world (Gaffney, 2014). The SDGs are goals to be shared all over the world which encompasses a shared mutual goal towards attaining a safe, just, and sustainable life for all people to prosper. SDGs mirror ethical ideologies that everybody and every country should be viewed as having a common duty to play their role in realizing the goals. Countries all over the world are striving hand in hand to eliminate poverty, reduce inequalities, and monitor climate change (Griggs, 2013).

The objective of this study is to examine the role of zakat distribution in the state of Kedah, Malaysia in assisting to achieve the goals of hunger and poverty elimination. This study is hoped to shed some light on whether the distribution of zakat in Kedah is in line with the goals, which could expand our understanding of the effectiveness of zakat distribution in achieving the objective of zakat. By having a good understanding of the distribution of zakat in Kedah, it could shed some light on suitable policies to be formulated zakat distribution in the future. It is important to understand the zakat distribution and its link to the goals of hunger and poverty elimination before any suitable policies could be planned, strategized, and implemented for improving zakat distribution in the future.

\section{Review of Previous Studies}

There have been limited studies on the relation between zakat and Sustainable Development Goals (SDGs). Asmalia et al. (2018) examined the potential of zakat to support financing and realizing Sustainable Development Goals (SDGs) in Indonesia. The study found that Muslims perceived elimination of poverty, quality education, and good health and well-being as being the highest priority which should be given as criteria in the distribution of zakat. The study revealed the potential of zakat in assisting the attainment of SDGs in Indonesia.

The SDGs are projected to be worldwide where it covers a shared common goal towards achieving a safe, just, and sustainable space for all people to prosper. SDGs mirror the ethical ideologies that everybody and every country should be viewed as having a common duty to play their role in realizing 
INTERNATIONAL JOURNAL OF ACADEMIC RESEARCH IN BUSINESS AND SOCIAL SCIENCES Vol. 10, No. 10, 2020, E-ISSN: 2222-6990 @ 2020 HRMARS

the goals (Osborn, Cutter, \& Ullah, 2015). Countries all over the world are striving hand in hand to eliminate poverty, among other goals (Griggs, 2013).

Some studies attempted to discuss the baffling task ahead of realizing the SDGs. Moldan et al., 2015) discussed the indicator for SDGs and revealed that it was a perplexing task to even start up the indicator for SDGs. To achieve the realization of SDGs, there are certain trade-offs and interconnections among the SDGs. Lu (2015) revealed that there might exist trade-offs amongst the SDGs depends on the scale. Blanc (2015) found that some SDGs were well connected among each other and the SDGs as a whole are a more integrated system than the MDGs. However, there are certain priorities on how scientific communities should come in to assist the realization of the goals, and among the main priorities are the elimination of hunger and poverty.

\section{Research Method}

This study employs a descriptive analysis to answer research objectives to provide empirical evidence and justifications to the analysis. This study employs secondary data on zakat distribution published by KSZB.

\section{Findings and Discussions}

In 2018, in line with SDGs, Kedah State Zakat Board (KSZB) set seven main cores of zakat distribution based on Sustainable Development Goals (SDGs) which include the elimination of poverty and hunger.

Table 1. Zakat Distribution According to Sectors in Kedah, 2018

\begin{tabular}{|l|c|c|}
\hline SECTOR & ZAKAT DISTRIBUTION (RM) & PERCENTAGE \\
\hline Cost of Living & $58,202,991.96$ & 41.02 \\
\hline Health & $3,007,017.09$ & 2.12 \\
\hline Housing & $12,100,944.06$ & 8.53 \\
\hline Business & $2,640,369.32$ & 1.86 \\
\hline Education & $45,673,916.20$ & 32.19 \\
\hline Misfortune & $1,584,590.50$ & 1.12 \\
\hline Development & $18,663,590.10$ & 13.16 \\
\hline Total & $\mathbf{1 4 1 , 8 7 3 , 4 1 9 . 2 3}$ & $\mathbf{1 0 0 . 0 0}$ \\
\hline
\end{tabular}

\section{Source: Zakat Info, Kedah State Zakat Board, 2018}

As shown in Table 1, zakat was distributed to seven core sectors: cost of living, health, housing, business, education, misfortune, and development sectors. The top of the list is the cost of the living sector which received RM58,202,991.96 (41.01 percent) of zakat distribution. This data indicates that Kedah State Zakat Board (KSZB) put the highest priority to the first core of zakat distribution based on the Sustainable Development Goal (SDG) which targets to eliminate poverty in all its forms in all places and the second core of zakat distribution to eliminate hunger. The first SDG's objective is to eliminate poverty for all people around the world, or at least reduce the proportion of people living in poverty by 50 percent. The second SDG attempts to eliminate hunger and safeguard that all people, particularly the poor can obtain safe, nutritious, and sufficient food (Griggs, 2013). 
INTERNATIONAL JOURNAL OF ACADEMIC RESEARCH IN BUSINESS AND SOCIAL SCIENCES Vol. 10, No. 10, 2020, E-ISSN: 2222-6990 @ 2020 HRMARS

Education receives the second-highest distribution at $\mathrm{RM} 45,673,916.20$ (32.19 percent) of the total distribution in 2018. This is in line with the fourth core of zakat distribution which targets quality education for all to ensure comprehensive and equitable quality education and promote life-long learning opportunities for all. There is a sense of urgency to assimilate sustainable development into formal education, informal and non-formal education opportunities

("https://www.un.org/sustainabledevelopment/sustainable-development-goals/," 2019). This goal is important because education could help those in poverty to attempt to get out of the cycle of poverty.

The development sector received the third-highest distribution at RM18,663,590.10 (13.16\%) of zakat distribution. This is in line with the fifth core of zakat distribution which targets to "promote sustained, inclusive and sustainable economic growth, full and productive employment and decent work for all". It is worth mentioning that improvement in employment would impact the goal to eliminate poverty and end hunger, therefore, there is a necessity to face the challenge of ensuring employment for all, particularly the youth

("https://www.un.org/sustainabledevelopment/sustainable-development-goals/," 2019). Besides giving zakat assistance, KSZB needs to provide proper training and skills as well as educate the recipients and equip them with the necessary skills and tools to increase income-generating employment opportunities for them not only to be ready to be employed but also to be entrepreneurs.

Furthermore, KSZB placed a great emphasis on housing by giving the housing sector RM12,100,944.06 (8.53\%). This is in line with the sixth core of zakat distribution which targets at providing sustainable cities and communities, which conforms to the UN's target of the eleventh SDG is ensuring a sustainable human settlements development which, among other things, attempts to provide adequate housing for all, develop human accommodation management, and promote the unified provision of water, sanitation, drainage, and solid waste management. It is worth mentioning that the housing sector allocation is for those living under poverty level.

Besides, KSZB also allocated zakat funds to health, business, and misfortune. Allocation to promote health is in line with the third SDG which targets safeguarding healthy lives and supporting the wellbeing of all people. There is a sense of urgency to fight a wide range of diseases and solve currently emerging health issues that are hoped to save lives. Furthermore, KSZB attempted to increase the standard of living by assisting the poor who aspire to be involved in business activities which are in line with the ninth SDG which attempts to provide infrastructure, promote inclusive and sustainable industrialization, and nurture innovation. The allocation to misfortune is necessary to help those who were hit by unfortunate calamities such as flood, fire, and accidents. This is in line with the second SDG which aims at eliminating hunger and provide the necessities of life particularly food.

In summary, this study reveals that zakat distribution in the state of Kedah, Malaysia in 2018 was in line with the goals of hunger and poverty elimination and there is great potential to achieve the goals. However, its success still depends upon the amount of zakat collection. Furthermore, the challenging task ahead is to formulate suitable indicators to measure the achievement of the goals of hunger and poverty elimination. 
INTERNATIONAL JOURNAL OF ACADEMIC RESEARCH IN BUSINESS AND SOCIAL SCIENCES Vol. 10, No. 10, 2020, E-ISSN: 2222-6990 @ 2020 HRMARS

\section{Conclusion}

This study reveals that Kedah State Zakat Board (KSZB) has made important strides towards achieving the goal of hunger and poverty elimination. Although there is a great potential to achieve the goals, its success still depends upon the amount of zakat collection in the future. The zakat collection needs to be increased further up to the target collection to have enough funds to be distributed to the recipients. Also, KSZB needs to plan, strategize, and implement a suitable and effective zakat distribution policy to speed up the process of achieving the goals of hunger and poverty elimination. This study recommends that LZNK make an annual budget plan in the future which comprises the annual estimate of zakat revenue and expenditure for the year 2020 and beyond so that zakat it would not run into budget deficit in the future.

\section{Acknowledgment}

We would like to express our appreciation to the Center for Islamic Finance Education and Research (CIFER), Sultan Abdul Halim Mu'adzam Shah International Islamic University for giving us support in conducting this study.

\section{Corresponding Author}

Yusuf Haji-Othman

Sultan Abdul Halim Mu'adzam Shah International Islamic University, Kedah Email: dryusufhajiothman@unishams.edu.my

\section{References}

Abd Halim, M. N., Saladin, M. A. R., Rashidah, A. R., Rozman, M. Y., \& Mariam, S. A. (2012). Assessing performance of nonprofit organization: A framework for zakat institutions. British Journal of Economics, Finance and Management Sciences, 5(1), 12-22.

Abu Bakar, N. B., \& Abdul Rahman, A. R. (2007). A Comparative Study of Zakah and Modern Taxation. J. KAU: Islamic Economics, 20(1), 25-40.

Ali, N. N. M., Taha, R., Embong, M. R., \& Nor, M. N. M. (2014). Developing a Multidimensional Performance of Zakat Collection System in East Coast Region. Procedia - Social and Behavioral Sciences, 164, 84-90. https://doi.org/10.1016/j.sbspro.2014.11.054

Asmalia, S., Kasri, R. A., \& Ahsan, A. (2018). Exploring the Potential of Zakah for Supporting Realization of Sustainable Development Goals (SDGs ) in Indonesia. International Journal of Zakat: Special Issue on Zakat Conference 2018, December 2018, 51-69.

Blanc, D. Le. (2015). Towards integration at last? The sustainable development goals as a network of targets (Vol. 1, Issue 141).

Gaffney, O. (2014). Sustainable Development Goals: Improving human and planetary wellbeing. Global Change, 82, 20-23.

Griggs, D. (2013). Sustainable development goals for people and planet. Nature, 5-7.

Hj Ibrahim, P. (2008). Pembanguan Ekonomi Melalui Agihan Zakat: Tinjauan Empirikal. Shariah Journal, 16(2), 223-244.

Lu, Y. (2015). Five priorities for the UN Sustainable Development Goals. Nature, 7-8.

Moldan, B., Billharz, S., \& Matravers, R. (2015). Sustainability Indicators : A Report On The Project On Indicators Of Sustainable Development (Vol. 1).

Norazlina, A. W., \& Abdul Rahim, A. R. (2011). Efficiency of Zakat Institutions and Its Determinants. 
INTERNATIONAL JOURNAL OF ACADEMIC RESEARCH IN BUSINESS AND SOCIAL SCIENCES

Vol. 10, No. 10, 2020, E-ISSN: 2222-6990 @ 2020 HRMARS

8th International Conference on Islamic Economics and Finance, 1-19.

Nur Barizah, A. B., \& Majdi, H. A. R. (2010). Motivations of Paying Zakat on Income : Evidence from Malaysia. International Journal of Economics and Finance, 2(3), 76-84.

Siddiqi, S. M. A. (1984). Early Development of Zakat Law and Ijtihad. J. Res. Islamic Econ., 2(1), 6973.

Triyuwono, I., \& Riduwan, A. (2012). Zakah Perspectives as a Symbol of lindividual and Social Piety: Developing a Review from the Meadian Symbolic Interactionism. Global Conference on Business and Finance Proceedings, 7(1). 